\title{
Entry Restrictions, Corruption and Extortion in the Context of Transition
}

\author{
Inna Č́belková* \\ Center for Economic Research and Graduate Education, \\ and Economic Institute, Academy of Sciences of the Czech Republic
}

\begin{abstract}
This paper argues that even temporary barriers to entry present at the very beginning of transition may lead to permanent extortion development. Entry restrictions, if binding, lead to excess profits, which create an incentive to extort. The emergence of extortionists reduces the expected profit from production, making producers expect extortion in the future. If, after this adaptation of expectations, the government removes the barriers to entry, only a few new firms will enter the market. Hence, the total number of firms on the market is lower than it would have been with no barriers to entry. The low number of firms on the market allows each producer to earn relatively high pre-extortion profits, which reinforces the desire of racketeers to take part of their wealth. Consequently, part of the population is permanently diverted from production to rent-seeking activities, which may slow down economic growth, even in the long run.
\end{abstract}

\begin{abstract}
Abstrakt
Článek demonstruje, že pokud je na počátku ekonomické transformace, byt' i jen krátkodobě, omezen vstup soukromých subjektů na trh, může dojít $\mathrm{k}$ dlouhodobému nárůstu korupce a vydírání. Nízká konkurence na trhu povede k obrovským profitům, které se stanou předmětem zájmu byrokracie a různých vyděračů. Rozbujením korupce a vyděračských aktivit dojde ke snížení očekávaných zisků firem, nebot' firmy začnou počítat $\mathrm{s}$ možností korupce a vydírání v budoucnu. Pokud překážky ke vstupu na trh zaniknou až poté, co si firmy vytvoří takováto pesimistická očekávání, využije volného př́stupu na trh jen málo nových firem. Celkový počet firem na trhu v dlouhodobém časovém horizontu tak bude nižší, než kdyby překážky ke vstupu na trh nikdy neexistovaly. Díky relativně nízkému obsazení trhu zůstanou hrubé profity firem (tj. profity před zaplacením vyděračům) relativně vysoké, což upevní přesvědčení vyděračů o ziskovosti jejich nekalého počínání. To povede $\mathrm{k}$ tomu, že část populace bude permanentně parazitovat na ostatních namísto toho, aby se spolupodílela na výrobě. Konečným důsledkem může být nižší ekonomický růst, a to i dlouhodobém časovém horizontu.
\end{abstract}

\section{Keywords:}

Corruption, extortion, transition.

JEL: P29, P36, K42, H89, J29

I would like to thank Randall Filer, Avner Shaked, and Gerard Roland for useful comments and suggestions. This work was supported by the Research Support Scheme of the Open Society Support Foundation, Grant No.: 265/1999.

\footnotetext{
*inna.cabelkova@cerge.cuni.cz
} 


\section{Introduction}

One of the greatest surprises of transition was the spectacular growth of corruption and extortion. ${ }^{1}$ According to Corruption Perception Indices (CPI), produced by Transparency International, the level of corruption in Russia in 1980-1985 was the same as of the Czech Republic, whereas in 1996 Russia found itself to have corruption close to that of India or Venezuela. According to the results of the survey by Frye and Shleifer (1997), 76\% of the shop owners in Russia "could not operate a store without paying for private protection". $90 \%$ of the managers of manufacturing firms in Russia and Ukraine stated that they pay for Mafia protection and that it is normal to pay bribes to government officials (Johnson, Kaufmann, McMillan and Woodruff, 1999).

It has not been fully explained yet why corruption and racketeering are more widespread in some countries then in others. For example only $15 \%$ of Slovak managers reported paying for private protection. The figure for Romania was even lower: $1 \%$ (Johnson, Kaufmann, McMillan and Woodruff, 1999). Only 8\% of the shop owners in Poland reported that it is not possible to operate a shop without paying for private protection (Frye and Shleifer, 1997).

The consequences of wide spread extortion and corruption on economic performance may be disastrous. Racketeers might weaken law enforcement via bribes, connections, blackmailing or threatening people responsible for enforcing the law. By demanding a part of the profits, the racketeers and corrupt officials increase the effective tax rate the firm should pay, and, thus, contribute to tax evasion and diminish the tax base. Insufficient tax revenue leaves the government with little resources for fighting law violations. Thus, if the level of extortion reaches a critical point, the country may be trapped in an unpleasant equilibrium

\footnotetext{
${ }^{1}$ In this paper I would like to talk about two types of rent seeking, which are somewhat interconnected: corruption and extortion. Extortion can be exercised by state officials and racketeers, and means demanding
} 
with low tax revenue, weak law enforcement, high extortion, and slow, or even negative, economic growth.

Economists are still debating the reasons behind the spread of extortion and corruption. Most of explanations claim that extortion occurs due to the inability of the government to enforce private contracts (see for example Hay, Shleifer and Vishny, 1996, Roland, 1999, Jonson, Kaufmann and Shleifer, 1997). The natural question, then, is why law enforcement is more effective in some countries of transition and than in others. There are two possible answers (Roland, 1999). Firstly, effective law enforcement is highly dependent on the amount of taxes collected. So, countries where tax collection is weak are likely to have poor law enforcement. The latter, in turn, aggravates the difficulty of tax collection: the weaker law enforcement is, the more profitable it is for firms to operate in the shadow economy. Secondly, the proportion of the citizens who violate the law can provide an answer. If most of the citizens of the country are law-abiding, law enforcement agencies are not likely to have too much work, and can operate more effectively in stopping the remaining law violations. In this case the probability of being caught is high, even if expenditures on law enforcement are not very large. However, if most of the population violates the law, the expenditures required for effective law enforcement are likely to be much higher. This way, at least two equilibria can emerge. In one of them lots of people violate the law causing a lack of resources for law enforcement and increasing the resources necessary for law enforcement to be effective. In the other equilibrium few people violate the law, the tax base and tax collection is sufficient, and the expenditures necessary for law enforcement to be effective are not too large (see Roland and Verdier, 1999). The question remains as to what leads a country to one equilibrium or the other. 
Before transition most of the post-communist countries had reasonable government revenue, and, thus, could afford sensible law enforcement. A repressive apparatus, which was often used under the communist regime for law-enforcement purposes, was well developed, especially in such post-Soviet countries as Russia and Ukraine. However, these are the countries, that had the biggest problems with corruption and extortion later on. What happened? This paper argues that the speed of private sector development might be one of the key determinants of the spread of corruption and extortion.

It is well known that the consumer goods sector under the communist regime was not very efficient in satisfying the needs of the population. Thus, there existed a huge market niche. Those who started to fill this niche first (either by producing or importing goods) were likely to earn fortunes. Goldman (1996) provides the following example: there was a group of people who started to make pantyhose. After approximately six months they became so rich that they closed down production because they feared that nobody would believe that they had made their money honestly. Similar stories might be told about those who started to import consumer goods or export raw materials. If, in such a case, the private sector develops quickly, enormous profits would likely dissipate and the market would become saturated. If there are barriers to entry, however, huge profits might become permanent. For potential racketeers or corrupt officials these profits represent wealth that they can easily grab. The higher the profits are, the more probable it is that extortion and corruption will develop.

Why can the speed of private sector development vary across countries in transition? There are at least two reasons. Firstly, citizens themselves might be more reluctant to start private businesses in some countries. Under communism, people were taught that a person who opens a private business is the enemy of the society, who should be hated and rejected by others. It is unreasonable to expect that such a notion, which was built during forty to seventy years, would disappear overnight. In addition, people who throughout their lives were used to 
relying on the state may not have wanted to take the responsibility for his/her prosperity him/herself. The unwillingness to risk might be aggravated by the lack of information and personal experience on how a market economy operates. Moreover, in the first stages of transition, there was virtually no legislative base for the private sector, and no one knew how legislation would look in the future. Finally, people were not entirely sure that transition was irreversible, and many of them still remembered the pain of collectivisation at the beginning of the communist era.

All these factors were present at different levels in all of the post-communist countries. For example in Poland, people were more willing to start private businesses since the private sector in this country was never eliminated completely. ${ }^{2}$ Moreover, Poland had experienced a communist regime for only forty years, which meant that there was still a generation that had personal experience with the market economy. On the other hand, most of the former Soviet Union had been exposed to a communist regime for a much longer time, and the notion of the market economy died with a past generation. Thus, the population was likely to be more reluctant to enter the market there.

The slow development of the private sector in some former Soviet countries was further hindered by entry restrictions imposed at the beginning of transition. In 1987 Mikhail Gorbachov partly lifted the ban on private and cooperative businesses. Students and pensioners but nobody else were allowed to enter the private sector ${ }^{3}$. Later, the ban was removed completely and the rest of the population was allowed to enter the private sector (this happened in January 1992 in Russia; see Åslund, 1999). During the five years between 1987 and 1992, therefore, there existed substantial barriers to entry to the private sector.

\footnotetext{
${ }^{2}$ In Poland 80 to 85 percent of farms were never collectivised.

${ }^{3}$ The shadow economy partially softened the entry restrictions but did not eliminate their impact completely.
} 
There might have been many reasons behind Gorbachov's decision to limit entry. Some observers argue that Gorbachov was fearful that if the private sector was open to everybody, the state sector would collapse (e.g. Goldman, 1996). The collapse of the state sector, however efficient the reduction of the state sector might be in the long run, was likely to lead to substantial short run problems. If the state sector collapsed, and the private sector did not develop quickly enough, the country would have to deal with high unemployment, a lack of traditionally available goods, fiscal difficulties, an uncontrolled increase in prices, and a weakening of the defence capacity of the country (weapons were produced exclusively in the state sector). These short run difficulties would cause the public to oppose transition, and might possibly lead to its reversal.

There might be several reasons why a quickly developing private sector may cause the collapse of the state sector. Firstly, the private sector may divert the most productive workers from the state sector, which may be detrimental for the latter.

Under the egalitarian ideology, there was a redistribution of material wealth from more productive individuals to less productive ones. If the private sector develops, it is likely to attract the most productive workers, thus destroying the redistributive equilibrium of the factory. Secondly, the private sector may increase the competition faced by the old-fashioned state sector enterprises, and thus cause the collapse of the state sector. The consumer goods produced in the state sector were often of poor quality and limited variety, since the consumer good sector was a low priority for the communist government. State enterprises were huge, and the management and central planning cumbersome. Under such conditions it was very difficult for state enterprises to quickly adjust to the changing demands of the population, and to withstand the possibility of foreign competition. Smaller private enterprises would have an advantage in this respect. Competition both from the domestic private producers and difficultto-control private importers may lead to the collapse of the state enterprises. 
In addition, a quickly growing private sector may cause a break in the production chain of the state enterprises. The communist-style state enterprises were organised into huge chains of large-scale production, ${ }^{4}$ where prices for intermediary goods and raw materials were understated. Newly emerging private firms might offer better prices for the intermediary products and raw materials, and, thus, "steal" vital products from the state enterprises. The private firms could then sell the intermediaries or raw materials on the international market and earn fortunes on the price margin. If the producer of the scarce intermediaries or raw materials is not able to increase production quickly, as is likely to be the case if the technological process is complicated, the emerging private sector firm may cause the collapse of production for many state factories.

Besides the fear that the state sector would collapse, communist leaders might have had a vested interest in postponing the development of the private sector. Facing no competition, they could earn fortunes on the export of the raw materials bought domestically on low, state-regulated prices. ${ }^{5}$

Very few life-changing decisions go smoothly through the government. Private sector development might have meant the end of many of communist leaders' power. It is, thus, possible that they opposed this possibility, and might have caused the slow down in transition, which manifested itself in barriers to private sector development.

Whatever the reasons for the slow development of the private sector were, it is likely that they would be temporary. The barriers to entry would eventually be abolished, and entrepreneurs would learn how to operate firms. Moreover, when the reluctant part of the

\footnotetext{
${ }^{4}$ This was seen by the communist leaders as one of the ways to hold the country together.

${ }^{5}$ According to Mr. Ekhanurov, the former director of a state enterprise in Ukraine, there were huge amounts of raw material accumulated just before the transition in the warehouses of the state factories. The reason was the policy of the Soviet government to evaluate the enterprise according to the amount of raw materials processed. Thus, it was in the interest of the manager to store the materials on the territory of the enterprise and report that they were already processed (Ekhanurov, 1999; presentation at Kiev-Mohyla Academy, Kiev, Ukraine).
} 
population realised the big profits the first entrants made, they would become more willing to open businesses as well. Would extortion and corruption survive? Unfortunately, it may.

Having little information on what to expect from private sector activity, new entrants are likely to rely on the experience of their predecessors. If extortion and corruption occurred when restrictions were imposed, new entrants are likely to expect that they will be extorted and that they will have to pay bribes as well. Consequently, fewer people would dare to open private firms, pre-extortion profits would not dissipate as much, and corrupt officials as well as racketeers would have more wealth to grab. This way expectations may reinforce extortion and corruption. This paper shows that this may happen though extortion and corruption would not have arisen without the temporary entry restrictions.

\section{Literature review}

This paper follows two trends in the economic literature. Firstly, it emphasises the role of expectations in economic development. Secondly, it sheds light on reasons why corruption and extortion developed to a larger extent in some countries than in others.

\subsection{Literature on the role of expectations}

The role of expectations in determining the equilibrium in multiple-equilibria games is receiving more and more attention in economic literature. In the field of international trade, Paul Krugman (1991) discusses the role of expectations in determining equilibrium in a simple model of international trade. In his model there is one factor of production and two goods. The production of one good is subject to constant returns to scale, whereas the other good is influenced by externalities, which ensure increasing returns to scale. The parameters of the model are such that if all individuals work in the constant returns to scale sector, 
nobody would find it profitable to work in the increasing returns to scale sector. Whereas, if all people work in the increasing returns to scale sector, it would not be profitable for one individual to start production of the constant returns to scale good. The choice of the equilibrium depends on the history and expectations of the population. If historically more than the critical fraction of people work in the constant returns to sale sector, the economy will end up in an equilibrium where none of the increasing returns to scale good is produced. Otherwise, none of the constant returns to scale good will be produced in the equilibrium.

Expectations may influence the choice of equilibrium. If for some reason people believe that all the others will work in the constant returns to scale sector, the economy will end up in this equilibrium. Similarly if the population believes that all other people would go to the increasing returns to scale sector, the economy will end up in this equilibrium. The reasons for different beliefs, however, are not discussed in the paper.

A similar argument was presented by Kiminori Matsuyama (1991) in his model of industrialisation. He shows that if returns to the manufacturing sector are increasing, the economy may end up in one of two steady states: one where the country is highly industrialised, and the other where nobody wants to work in industry. The choice between the stationary states depends both on the history of employment and on self-fulfilling prophecies.

The possible influence of expectations on the choice of equilibrium is also discussed in the industrial organisation literature. Farrell and Saloner (1986) present a model of technology adoption. In their model returns from technology are subject to whether the others adopt the technology as well. They find that for some parameters multiple equilibria are possible. If for some reason all the individuals believe that the others will adopt the technology this equilibrium is possible. Otherwise, the technology is not adopted.

In the field of macroeconomics, expectations are important, especially in search models where the profitability of participating in economic activities depends on how many 
other agents participate. The more individuals do business, the more trades are made, and the larger are the potential profits from participating (see Diamond and Fudenberg, 1978, and Howitt and McAfee, 1988). Unfortunately most of these papers do not discuss the reasons for different expectations.

\subsection{Literature on the development of extortion and corruption}

Many of the authors writing on the reasons for extortion development argue that it occurs when the government is not able to enforce private contracts or to provide law and order. In this situation some firms are destined to rely on private law enforcement provided by mafias.

Jonson, Kaufman and Shleifer (1998) present a model of competition between the government and the mafia in the provision of law and order. People decide whether to work in the official or shadow economy depending on the "amount" of law and order in these sectors. Entrepreneurs would prefer to work in the shadow sector if that provides them with more efficient enforcement of contracts or clearer property rights. If the state sector is better in the provision of order, they choose to work in the official economy. In the model two equilibria are possible: either the whole population works in the official sector, or all people work in the shadow sector. The latter case causes the collapse of the government.

The crucial assumption in the Johnson, Kaufman and Shleifer model is that no tax revenue is used to combat economic crime. Roland and Verdier (1999) relaxed this assumption. They assume that if somebody enters the underground economy, he necessarily joins the mafia and become a predator. The initial value of the proportion of the population which decides to become predators is assumed to be exogenous. The matching between producers and predators is assumed to be random, i.e. a producer meets a predator with 
probability $\alpha$ and a producer with probability (1- $\alpha)$. If a producer meets a predator, he is robbed of his income. If a producer does not meet a predator, he is taxed by the government. The revenue collected by the government is used to finance law enforcement.

There are two co-ordination problems here. Firstly, the more predators there are, the higher the probability that a producer is robbed. Secondly, the more predators there are, the less tax revenue the government collects, and the weaker its ability to enforce laws. Here again two stable equilibria are possible: either there are no producers, or there are no predators.

In order to destabilise the first equilibrium the authors suggest that the government keeps control over resources, so that it has enough power to control the economy not relying only on tax revenue. This control, however, leads to inefficiency.

Even if the government is able to provide law and order and enforce contracts, the mafia can still develop if the tax rate is high and regulations are cumbersome. In order to avoid excessive taxation firms may choose to operate in the shadow economy where they are subject to Mafia demands and protection (Johnson, Kaufmann, Shleifer, 1997).

Very original work on the emergence of rent seeking was done by Savvateev (1998). He discusses the impact of heterogeneity in labour endowments within the population on the spread of extortion. He showed that if the differentiation in labour endowments is sufficiently big and production is inefficient, more than fifty percent of the population is likely choose for the rent-seeking regime since their productivity is so low that it would not pay them to produce.

I would like to propose another reason why corruption and extortion might be more widespread in some countries than in others. It seems possible that extortion and corruption will be more likely to develop if there is more extra wealth that is easy to grab. This wealth may be generated by the slow speed of private sector development, which would allow for 
huge profits for the first comers. The permanent nature of the effect depends heavily on the expectations of the population. Contrary to the most of the literature on the influence of selffulfilling expectations on economic development I would not have to assume here that expectations are ad hoc. They depend on the history of events and on the propensity of the population to learn from their predecessors.

\section{The model of extortion}

Whether extortion will occur if the speed of private sector development is low depends on whether it is more profitable to extort if the profits of the firms are high. Naturally, richer private firms may hire better private security, and, thus, substantially restrain extortion. In addition, profits from extortion depend on how many people engage in extortion: the more extortionists there are, the less wealth there is to be grabbed on average. Finally, the profit from extortion may depend on the profit of the industry as a whole: it is not clear whether the latter would increase or decrease with the number of firms. This section discusses all the points presented above. I start with a very simple model of extortion, which analyses the interactions of one extortionist and one manager, to show that the profit of the extortionist increases with the profit of the firm. Then I apply the results to different extortion market structures. Finally, I analyse the influence of the speed of private sector development on the spread of extortion, taking into account returns to scale in the productive industry.

\subsection{The "one extortionist, one firm" case}

There is one extortionist and one manager of a private firm. The manager owns the firm. The extortionist is assumed to be fully informed about the profit of the manager, and decides how much to demand. Facing extortion the manager can call the police or private 
security. The interactions of the manager and the extortionist can be represented by the following game tree. 
Figure 1. Extortion game

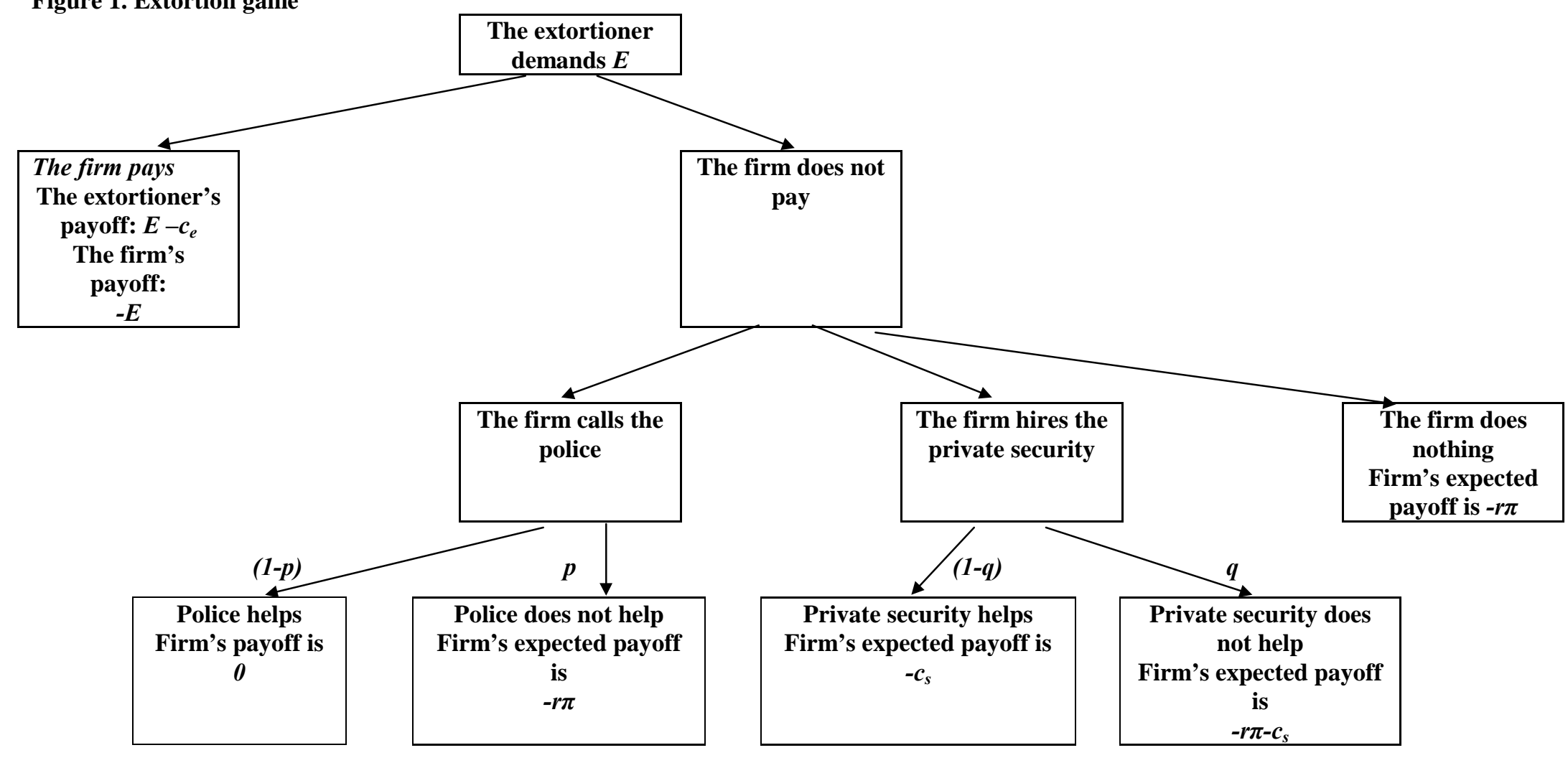

\begin{tabular}{|c|c|c|c|}
\hline $\begin{array}{c}\text { Overall payoff of } \\
\text { the firm if it does } \\
\text { not pay }\end{array}$ & $\begin{array}{c}\text { It calls the police } \\
(1-p) 0-p r \pi\end{array}$ & $\begin{array}{c}\text { It hires private security } \\
(1-q) 0-q r \pi-c_{s}\end{array}$ \\
\hline
\end{tabular}


Let the cost of extortion be $c_{e}$. This cost includes both the cost of demanding payments from the firm and the cost of scaring the firms (reputation building). Abstracting from methods of how reputation is built, assume that the fear of the manager is an increasing function of the costs of extortion. ${ }^{6}$

Let $r$ be the proportion of profit that the manager of the firm expects to lose if he does not pay off the extortionist and if nobody helps the manager get rid of extortionist in other ways. This proportion represents the fear of the manager. It includes both the perceived probability that the extortionist can damage the firm and the perceived magnitude of the loss.

$r=f\left(c_{e}\right)$

$f^{\prime}\left(c_{e}\right)>0$

The extortionist demands $E$ from the private firm manager. If the manager pays, he loses $E$ and the extortionist gains $E-c_{e}$ (see figure 1). If the manager does not want to pay, he has three options: to call the police, hire private security or do nothing. Assume that he cannot call both the police and private security simultaneously.

Police are free whereas private security is costly. Let the cost of private security be $c_{s}$. Let $1-q$ be the probability that the private security succeeds to help the firm get rid of the extortionist. Let $1-p$ be the probability that police helps the firm. It is natural to suppose that the private security is more successful in fighting extortionists (otherwise it would not be able to compete with the police), therefore

$p>q$.

Let $\pi$ be the pre-extortion profit of the firm. 
Under this notation if the manager calls the police, his expected pay-off is - $p r \pi$.

If the manager calls private security, his expected profit is $-q r \pi-c_{s}$.

The expected profit from doing nothing is $-r \pi$.

\section{Proposition 1}

The higher the manager's profit, the higher the profit from extortion, even if the manager has an option of hiring private security or calling the police

\section{The manager's problem}

The manager minimises possible losses:

$\min$ [loss if the firm pays, if it calls the police, if it pays private security, if it does nothing].

That is,

$\min \left[E, \operatorname{pr} \pi, q r \pi+c_{s}, r \pi\right]$.

Assume that the firm can not borrow the money in order to pay for private security, as would mostly be the case at the beginning of transition. ${ }^{7}$ Thus the following constraint must hold

$\pi \geq c_{s}$

\section{The extortionist's problem ${ }^{8}$}

The extortionist maximises his payoff subject to the constraints that the firm pays

$\max \left(E-c_{e}(r)\right)$

$E, r$

\footnotetext{
${ }^{6}$ One can imagine for example that the extortionist damages several firms at the very beginning of his activity making the others scared of him. In addition in order to scare the firm the extortionist can buy weapons, go to gym so that he looks big, etc.

${ }^{7}$ If this assumption is relaxed the results still hold.

${ }^{8}$ Here we will analyse the Nash equilibrium, so it is not important for us what the monopolist will lose if the police are successful (as would be the case of Trembling Hand Perfect Equilibrium). However, this risk is partially included in the costs of extortion.
} 
subject to the fallowing conditions

1. it is better for the firm to pay than to call the police

$E \leq p r \pi$,

2. it is better for the firm to pay than to call the private security if

$E \leq q r \pi+c_{s}$

but only if : the firm has enough money to call the private security (borrowing constraint) and

$\pi \geq c_{s}$

3. it is better for the firm to pay than to do nothing

$E \leq r \pi$.

Since $p<1$, if condition 1 is satisfied, condition 3 is also satisfied. Thus we can exclude the latter from further analysis.

Case 1. The profit of the firm is high enough to allow the manager to hire private security when he finds it profitable to do so (condition 2.a. is not binding).

Let us plot the conditions one and two: 
Figure 2. Conditions 1 and 2

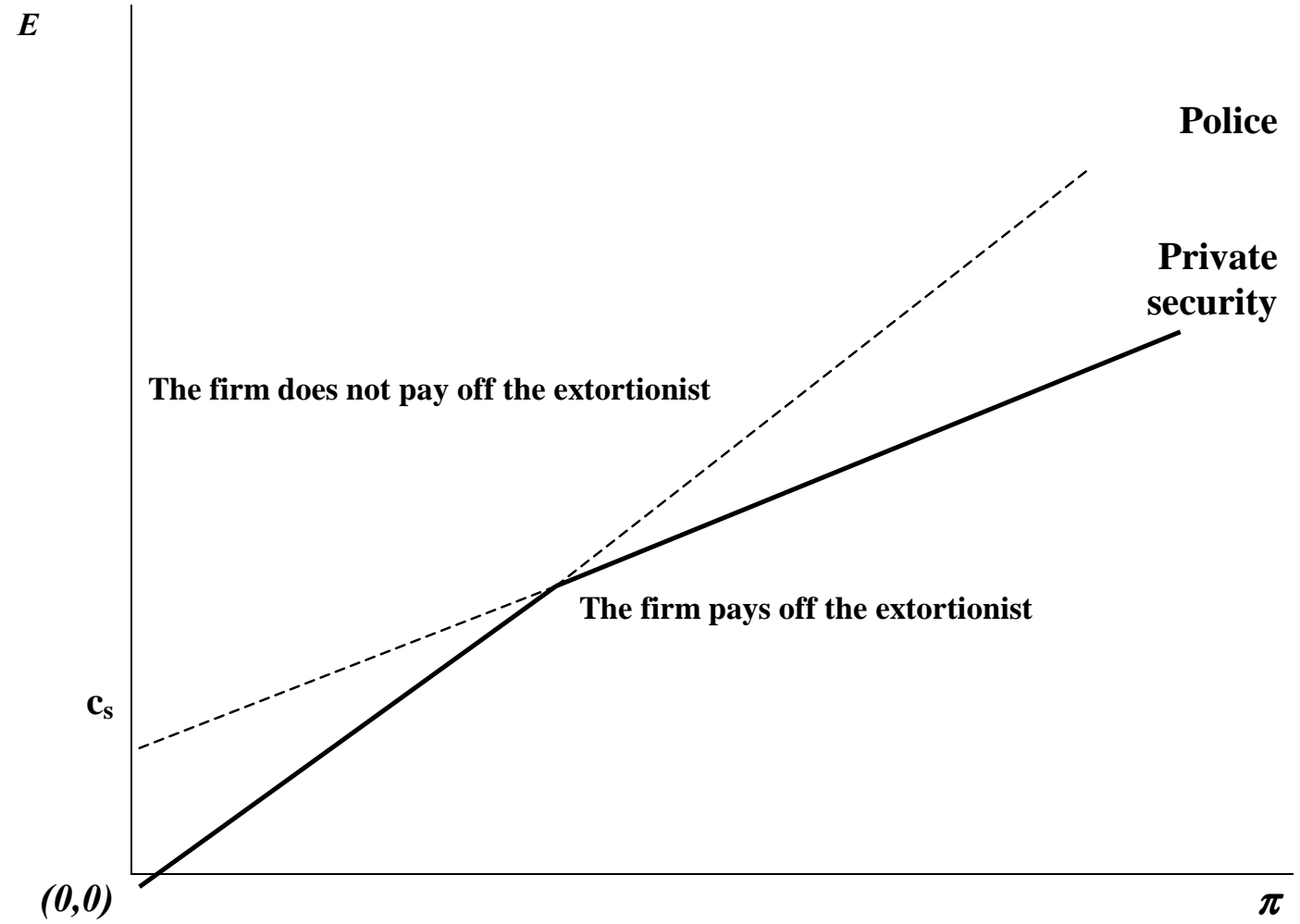

If the perceptions of the manager about possible loss $(r)$ are constant, the profit from extortion increases with the profit of the firm. If the extortionist chooses to alter $r$ as a response to the increased profit of the firm he will always do this in a way that will make him even better off. Thus his profit will always increase.

Note that if the manager gets more scared ( $\mathrm{r}$ increases), the whole picture rotates around $(0 ; 0)$ as shown on Figure 3, and the firm manager chooses to hire private security with lower profits (point of intersection $\mathrm{O}$ shifts leftward). ${ }^{9}$ If Point $O$ reaches a certain minimal value, condition 2.a starts to be binding.

\footnotetext{
${ }^{9}$ It is easy to prove this using basic algebra.
} 
Figure 3. Comparative analysis

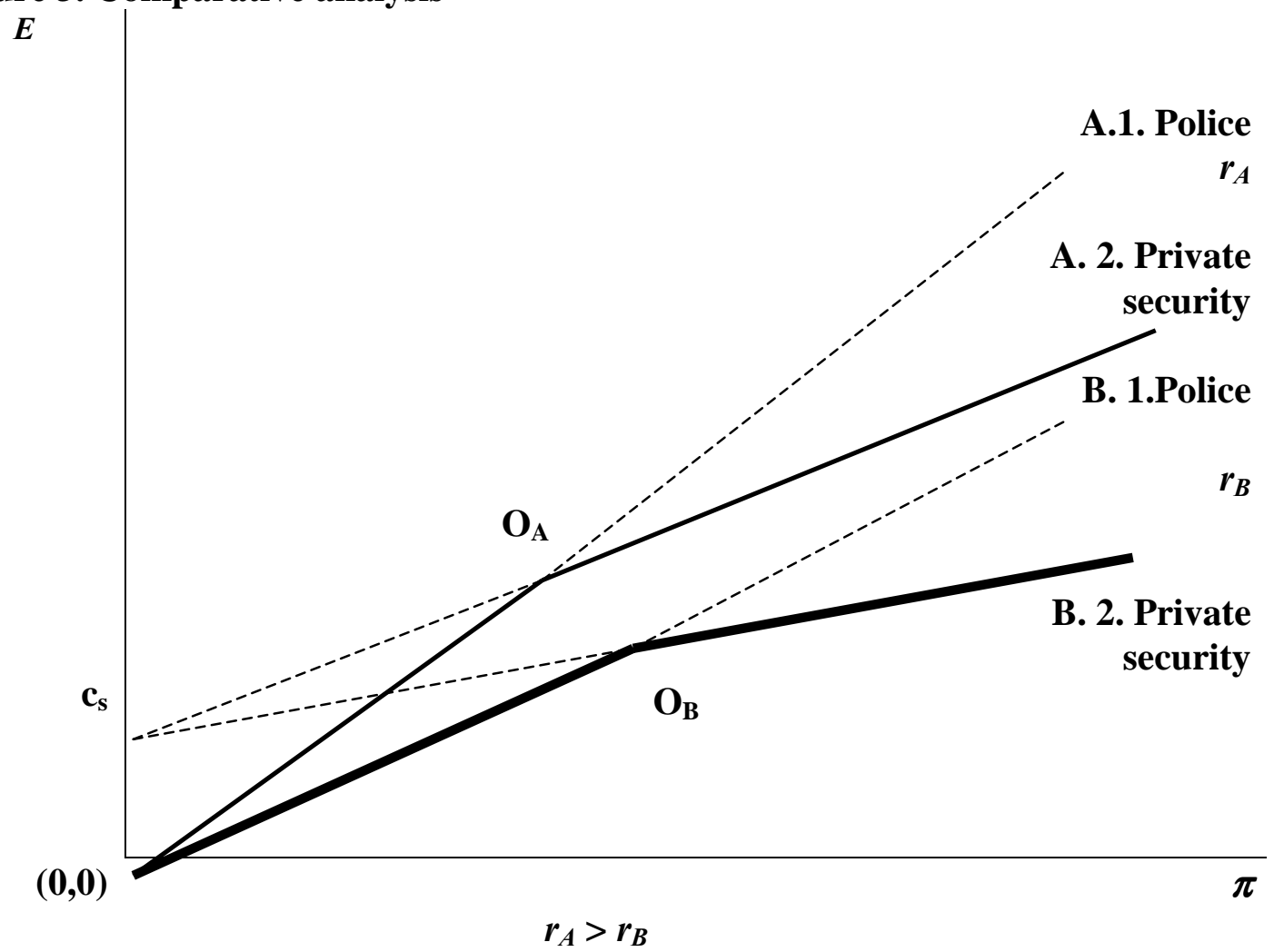

Case 2. The borrowing constraint is binding

It may happen that the extortionist is able to scare the manager of the firm so much that the latter would prefer to hire private security even if the profits are so low that he is not actually able to pay the private security. ${ }^{10}$ In this case the picture will be the following:

\footnotetext{
${ }^{10}$ The manager may fear that the extortionist will kidnap his close relatives or that the extortionist will kill him.
} 
Figure 4. The borrowing constraint is binding

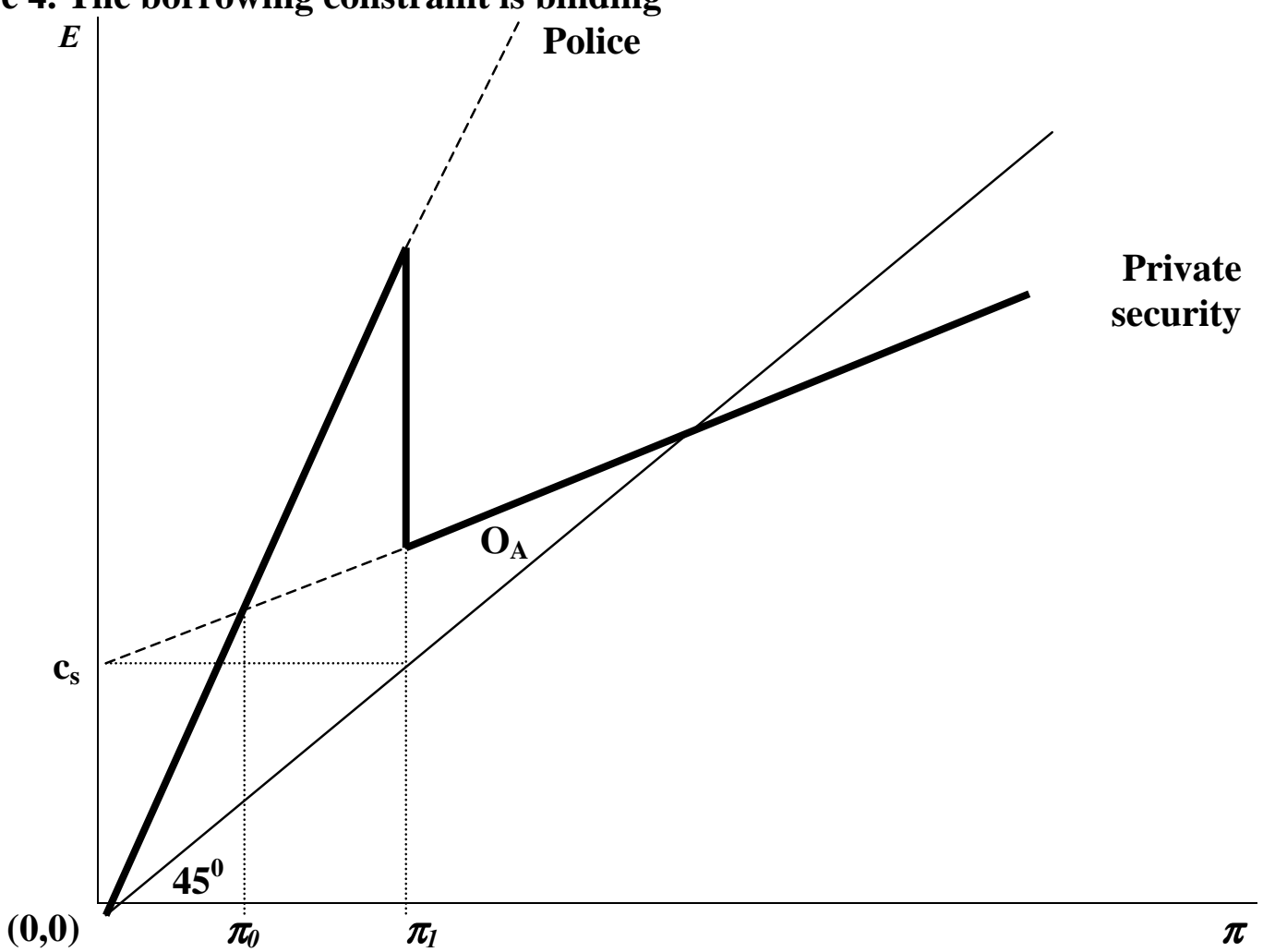

If the profit of the firm is less than $\pi_{l}$ but greater than $\pi_{0}$, the firm's manager will want to hire private security but will not have the resources to do so. The profit curve of the extortionist in this case is discontinuous, and there exists a jump where it decreases with the profit of the firm.

However, as can be easily seen from geometric analysis, the jump occurs only if the line representing the constraint of calling the police is steeper than $45^{\circ}$ (otherwise $\pi$ is always greater than $c_{s}$ ). The following will show that this may not happen unless the extortionist is able to extort from the manager more than its profit, which seems to be a reasonable assumption.

\section{Conditions for the line to lie below the $45^{\circ}$ line}

$\operatorname{pr} \pi<\pi$.

The conclusion on whether this condition is satisfied hinges on whether $p r$ is greater or less than one. Probability $p$ is always less than one. The perceived probable loss of 
the firm $(r)$ is the composite of two factors: the perceived probability that the extortionist fulfils the threat and the perceived loss for the firm if the threat is fulfilled. The latter is expressed as a proportion of the manager's profit:

$r=\beta \gamma$

$\beta<1$ is the probability that the threat is fulfilled, and

$\gamma$ is the perceived loss for the firm.

Generally, $\gamma$ may be greater than one. The extortionist may kidnap the manager's family, destroy the enterprise, etc. If $\gamma$ is large enough, the jump will occur. Would it be profitable for the extortionist to scare the manager that much?

It seems reasonable to assume that the maximum payment the extortionist can get from the manager of the enterprise is the manager's profit. Thus, the maximum payment to the extortionist depending on the profit of the firm would lie on the $45^{\circ}$ line.

In the case of the jump, the extortionist evokes a fear he may not take advantage of. Since the fear is assumed to be an increasing function of the cost of extortion, it is not profitable for the extortionist to scare the manager that much.

In the following analysis I exclude the case of the jump. Therefore, I can conclude that the profit from extortion increases with the manager's profit. Would this result hold if there are several security firms on the market?

\section{Case 3. Several security firms on the market}

Assume that each security firm offers a bundle: price versus quality of service. If the market is competitive and there is no arbitrage opportunity, the higher is the price, the better the quality must be. 
Figure 5. Many security firms

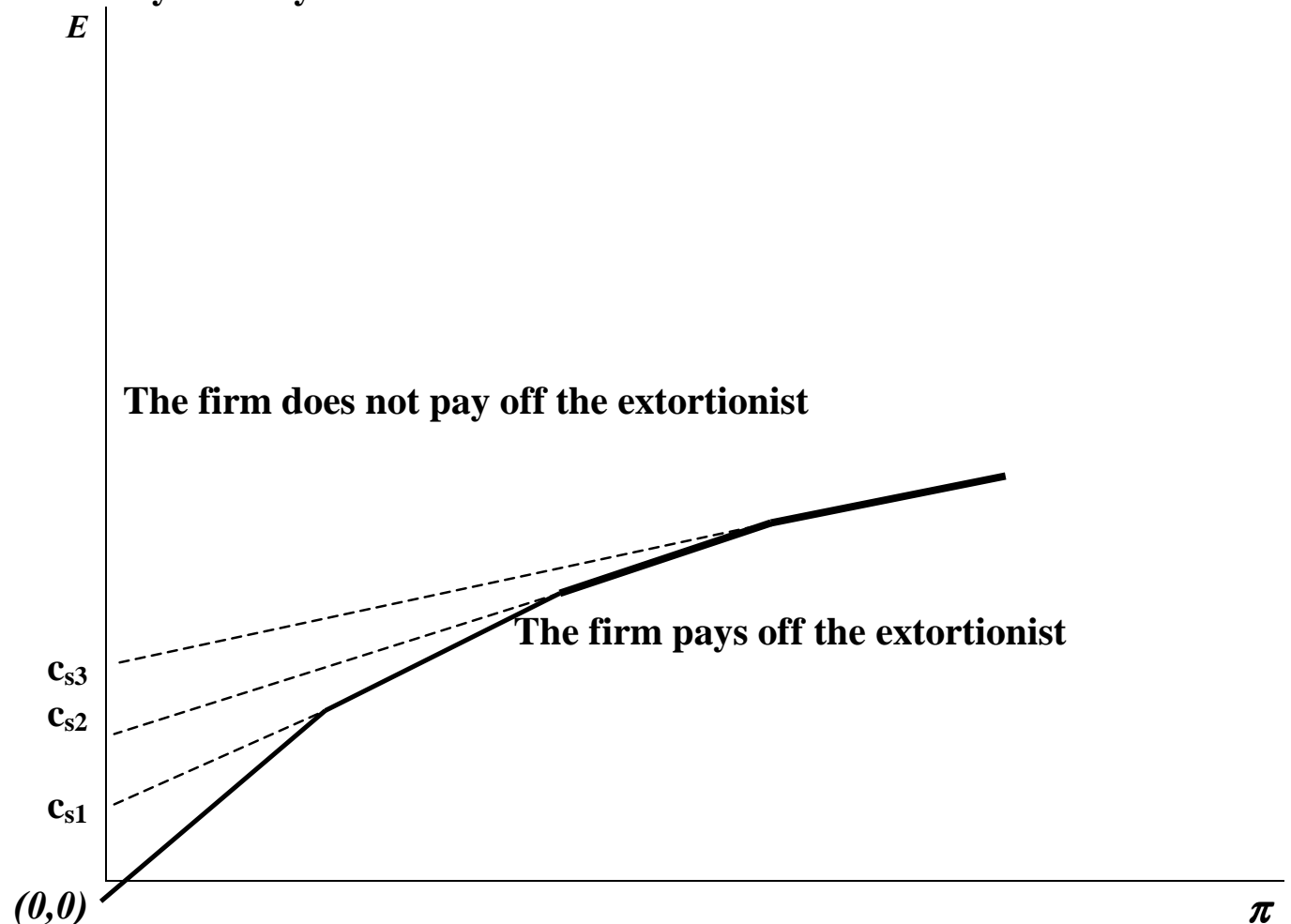

The amount that the extortionist can demand still increases, and following the logic from Case 1, his profit will increase as well.

Q.E.D. 


\subsection{Many firms, many extortionists case}

Would the profit from extortion increase with the profit of the firm in this case? There are two factors influencing the profit from extortion. Firstly, the bigger is the number of extortionists, the less wealth-to-extort is left for each new extortionist, independently of the firms' profits. Secondly, the structure of the market for extortion matters. In the following I analyse several extortion market structures and for each of them conclude whether the profits of the firms influence the profits from extortion. For simplicity let's assume that extortionists divide the territory of influence so that one firm can be extorted only by one extortionist.

\section{Case 1. Very few extortionists (no competition between extortionists)}

This might be the case when extortion is not developed very much. If there are very few extortionists, all of them can extort from as many firms as they find profitable given the cost of extortion.

The profit from extortion is

$\pi_{e}=E\left(\pi_{f}, r\right) N_{f}-c_{e}\left(N_{f}, r\right)$

where

$E\left(\pi_{f}, r\right)$ is the amount extorted from one firm,

$N_{f}$ is the number of firms extorted by one person,

$\pi_{f}$ is the profit of one firm, and

$c_{e}\left(N_{f}, r\right)$ is the cost of extortion. 
It is reasonable to assume that the cost of extortion is an increasing function of the number of firms one extorts from, and that the cost is an increasing function of how much the managers fear the extortionists, since fear building is costly. ${ }^{11}$

If the profit of one firm increases, the amount that can be extorted from it increases as well (follows from proposition 1). If the extortionist will not change the number of firms he extorts from and the investment in threatening the managers does not change, his profit will increase with the profit of one firm. If he will choose to alter the number of firms he extorts, or to threaten the managers more, he will do this in the way that will make him even better off. So, if extortion is not competitive, the profit of one extortionist strictly increases with the firms' profits.

\section{Case 2. Entry to extortion is free, there are many extortionists (perfect competition)}

The profits of the extortionists will be driven down to the opportunity income plus some risk premium, no matter what the profits of the firms are.

\section{Case 3. No entry to extortion possible (gangs have divided the spheres of influence and protect them from new entrants into the extortion business)}

Under the condition that the one-firm profit depends negatively on the number of firms on the market, there are two contradictory tendencies. The higher the one firm's profit is, the more the racketeer can get from it; however, there are fewer firms that he can extort from since number of firms is negatively associated with one firm's profit.

For simplicity let's assume that

\footnotetext{
${ }^{11}$ Generally, the cost of extortion is likely to depend on the firm's profit. This dependence is taken into
} 
- each gang consists of one individual,

- the shares of the extortion market are equal for all the extortionists (symmetric case),

- there are $N_{e}$ extortionists on the market.

Then the profit from extortion is the following:

a) if the constraint of calling the police is binding,

$\pi_{e}=p r \pi_{f} N_{f 1} / N_{e}-c_{e}\left(N_{f 1} / N_{e}, r\right)=p r \Pi_{p} / N_{e}-c_{e}\left(N_{f 1} / N_{e}, r\right)$

where $N_{f l}$ is the total number of private firms, and

$\Pi_{p}$ is the total profit of the private sector.

If one-firm's profit increases, or, equivalently, the number of private firms decreases, the second term in the expression above decreases. The first term may increase or decrease depending on returns to scale of the private sector production function and the functional form of the cost of extortion.

b) If the constraint of hiring private security is binding,

$$
\pi_{e}=\left(q \pi_{f} r+c s\right) N_{f 1} / N_{e}-c_{e}\left(N_{f 1} / N_{e}, r\right)=q r \Pi_{p} / N_{e}+c_{s} N_{f 1} / N_{e}-c_{e}\left(N_{f 1} / N_{e}, r\right) .
$$

The profit of one extortionist may either increase or decrease with the number of private firms depending on returns to scale in the private sector, and the functional form of the cost of extortion.

Thus, if extortion is competitive, but entry to extortion is limited, the profit of one extortionist may be an increasing or decreasing function of the firm's profit (or, equivalently, of the number of private firms).

account via the fact that a more profitable firm is able to hire better private security. 


\subsection{Three stage analysis with entry restrictions and expectations. Can temporary entry restrictions lead to permanent extortion?}

In this section I apply the results from the previous sections to a three stage game and prove that there exists a non-empty interval of costs of extortion in which extortion would occur if barriers to entry initially exist and remain after they are abolished, although extortion would not occur if the barriers to entry never existed. In other words, there exists a non-empty interval of the costs of extortion so that even temporary barriers to entry cause long-term extortion.

\subsubsection{Entry costs of extortion are negligible}

Assume that there are $\mathrm{N}$ individuals who initially work in the state sector.

Consider the following three stage game:

At stage zero there is no private sector in the economy. The citizens must satisfy their demands with state sector goods. However, state sector enterprises are not responsive to the actual needs of the consumers. Thus, there exists a huge market niche, which may potentially be filled by the private sector.

At the first stage the government decides to open up the private sector. However, there are certain barriers to entry. Only $N_{1}<<N_{\max }$, where $N_{\max }$ is the maximum number of firms that are profitable on the limited competitive market, people can start businesses. Assume that each firm employs only one person, who is the owner of the firm. All the firms in the private sector produce homogeneous goods.

Continue with the assumption that the profit of one firm is a decreasing function of the number of firms on the market. 
In order to exclude the obvious case when it is not profitable for all of the people allowed to start businesses, assume that

$N_{l}<<N_{\max }$

where $N_{\max }$ is the maximum number of firms in the industry who are still able to survive in a competitive market, i.e. earn profits that are at least equal to the opportunity income of the managers.

$\pi>>w$

where $\pi$ - is the profit of one firm,

$w-$ is the opportunity income of its owner. ${ }^{12}$

At the second stage people who are not allowed to start private businesses observe the profits of the private firm managers and decide whether to continue their current employment or to extort the private firms.

At the third stage the entry restrictions are removed and all the agents decide on whether to work in the private sector, continue their employment in the state sector or to extort the private sector. ${ }^{13}$

\section{Figure 6. Three stage game}

First stage

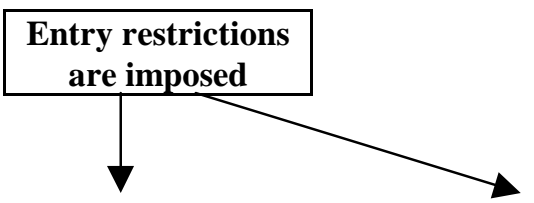

\footnotetext{
${ }^{12}$ If the entry restrictions are government imposed, it is possible that those who are not allowed to start private business officially would do so illegally. The shadow firms are likely to soften the entry restrictions.

${ }^{13}$ One can also consider that first private firm managers may expect that in the next period barriers to entry will be removed, and may choose to prevent possible entry. If one excludes possible collusion with government officials, there is at least one way they can do this: the incumbents pretend that their cost of production is very low so that potential entrants would not find it profitable to start private businesses. This strategy implies that the incumbents in the second stage set prices lower than the marginal cost (otherwise nobody would believe that they are low cost), thus their profits in the first period are low as well. This move, however, would require sufficient start up capital and clear predictions for the future. None of these features were present in the countries of transition. It seems more reasonable to suppose that the aim of the first comers was to build the initial capital making the most of their exceptional position on the market.

Another way to prevent possible entry is to invest in advertising. However, this step again implies the existence of sufficient start up capital and clear predictions for the future.
} 


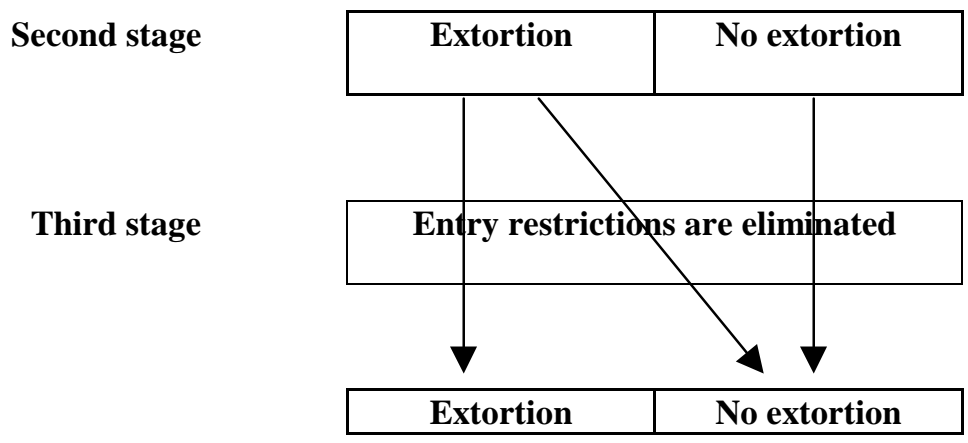

Statement 1. If the costs of extortion are in some interval $\left(c_{l} ; c_{h}\right)$ temporary barriers to entry may cause the permanent spread of extortion.

Stage two

The barriers to entry limit the number of firms on the market, thus increasing the profits of those who are allowed to start their businesses. ${ }^{14}$ Higher profits will increase the revenue of potential extortionists (follows from proposition 1) thus making it more profitable to extort. Two cases are possible:

- If the entry restrictions are not severe, so that the profits of the private firms are low enough, and/or the costs of extortion are high enough $\left(c_{e}>c_{h}\right)$, extortion may not occur. $^{15}$

- Otherwise, extortion will occur.

\footnotetext{
${ }^{14}$ This follows from the assumption that the profit of one firm decreases with the number of firms on the market. The latter might be caused, for example, by Cournot competition between the firms.

${ }^{15}$ In order to simplify notation, from now on I will denote the cost of extortion as scalar, whereas in reality this is the function which depends on the number of the firms extorted and the reputation built (r). The upper and lower boundaries of the scalar should then be understood as the upper and lower boundaries of the set of functional forms. The use of the notation and the proofs are so intuitive that I think that such simplification should not lead to any mathematical misunderstanding.
} 
Is the emergence of extortion the result of the barriers to entry? Arguably, if the cost of extortion is low enough $\left(\mathrm{c}_{\mathrm{e}}<\mathrm{c}_{\mathrm{l}}\right)$ extortion might occur even if there are no barriers to entry.

However, for a given barrier to entry there exists a non-empty set of $c_{e} \in\left(c_{l} ; c_{h}\right)$ such that extortion occurs if this barrier to entry is imposed and does not occur if it is not imposed.

\section{Proof}

The first extortionists are not likely to face competition. Later on, competition may emerge and will drive the extortionists' profits down. ${ }^{16}$ Thus, it is the non-competitive profit of the extortionist that ensures the occurrence of extortion. As we have already proven, an extortionist's profit increases with the firm's profit. Thus, there exists a set of extortion costs such that extortion would occur if there are barriers to entry while it would not have occurred if entry restrictions were never imposed.

Formally, extortion will occur if the profit exceeds the opportunity income plus risk premium:

$\pi_{e}=E\left(\pi_{f}, r\right) N_{f}-c_{e}\left(N_{f}, r\right)>w+R$.

Let $\pi_{f b}$ be the profit of the firm with barriers to entry and $\pi_{f n}$ be profit of the firm without barriers to entry:

$\pi_{f b}>\pi_{f n}$

Then costs, satisfying the following requirement will ensure no extortion if there are no barriers to entry, and the existence of extortion if there are barriers to entry:

$w+R-E\left(\pi_{f b}, r\right) N_{f}>c_{e}\left(N_{f}, r\right)>w+R-E\left(\pi_{f n}, r\right) N_{f}$.

\footnotetext{
${ }^{16}$ However, the competition among extortionists will not eliminate extortion.
} 
The set of $c_{e}\left(N_{f}, r\right)$ is non-empty since the amount extorted from one firm $E\left(\pi_{f b}, r\right)$ is an increasing function of $\pi_{f}$.

Q.E.D.

From now on let us discuss the most interesting case when extortion takes place if the barriers to entry are imposed, while it does not occur if there are no barriers to entry. Stage three: entry restrictions are abolished

New entrants can start firms, and the one-firm profits fall.

The entry condition for the new firm depend on the expectations on whether the firm will be extorted and may be generally written as

$E(\pi) \geq w+$ expected extortion

In this case two equilibria are possible: extortion may or may not remain. The choice of the equilibrium is determined by the expectations of the population. If the population expects that extortion will be eliminated, many new private firms will be opened driving the one-firm profits down to the opportunity income. Such a reduction of one-firm profit will lead to the elimination of extortion. ${ }^{17}$

If the population thinks that new firms will be extorted, and in the transition countries it seems sensible to believe so, extortion may remain. Expecting extortion, fewer people will want to start businesses. Consequently, the pre-extortion-one-firm profit will be greater. Higher profits may lead to an equilibrium where extortion survives, whereas it would not occur if the barriers to entry were never imposed. ${ }^{18}$ Thus, temporary entry restrictions may lead to the permanent spread of extortion.

\footnotetext{
${ }^{17}$ This is equivalent to the case when extortion never existed. Remember that we assumed that the costs of extortion are such that it does not pay to extort if the market is competitive.

${ }^{18}$ The logic of the proof for this statement is similar to the proof above. Note that the entry to extortion may or may not be free, and, thus, profits from extortion may or may not exceed the opportunity income
} 


\subsubsection{Extortion with entry costs, or whether it is optimal for the government to announce that entry restrictions are temporary}

Suppose that there is a fixed entry cost of extortion. This cost is paid only once when the potential extortionist enters the business. One might think of it as the cost of reputation building (it is much more difficult to build a reputation as a brutal extortionist from scratch than to maintain it later on), or struggling for an area of influence in the war between gangs. This fixed cost may be another reason for the permanent spread of extortion as the result of the temporary barriers to entry. The intuition behind this statement is that if extortionists do not know that the entry restrictions will be removed, their perceived prospective profits might be high ${ }^{19}$, and they would choose to start extortion. When the barriers to entry are removed, it might not be profitable for the new extortionists to enter (they still have to pay the fixed entry cost), but it might be profitable for the old extortionists to continue to extort since they now have to pay only the variable cost of extortion. The formal analysis is the following:

Assume the extortionist maximises two stage sum of profits ${ }^{20}$

$\Pi_{e}=-F+\pi_{e 1}+\pi_{e 2}$

where $\pi_{e 1}$ and $\pi_{e 2}$ are the total revenues from extortion net of variable cost of extortion in stage one and two. $F$ is the fixed entry cost. If this sum of profits is greater than two stage opportunity income plus risk premium, the extortionist decides to extort.

of extortionists plus the risk premium. The industrial organisation of extortion is not important to deduce whether extortion will or will not survive. Only the monopolistic extortion case matters.

${ }^{19}$ This may happen if the extortionists manage to close entry to extortion fairly quickly after extortion emerges. Otherwise, as was discussed above, one extortionist's profit does not depend on the profit of the firms.

${ }^{20}$ Alternatively we can assume that the extortionist maximises the discounted stream of future profits. 
Imagine three situations: there are no entry restrictions for the private sector (case one); there are entry restrictions, but the extortionist does not know that they are temporary (case two); there are entry restrictions, the temporary nature of which is known to the extortionist (case three). Denote $\pi_{e b}$ as the one period revenue of the extortionist net of variable cost if the barriers to entry are imposed and $\pi_{e n}$, if there are no barriers to entry.

If

$\pi_{e b}>\pi_{e n}$

as is the case if extortion is not competitive or may be the case if extortion is competitive but the number of extortionists is limited, then the expected two-period profits of the extortionist can be written as the following cases:

1. no entry restrictions to the private sector,

$\Pi_{e l}=-F+\pi_{e n}+\pi_{e n}$

2. entry restrictions are imposed but the extortionist is not aware of their temporary nature,

$\Pi_{e 2}=-F+\pi_{e b}+\pi_{e b}$

3. the extortionist knows that the restrictions are temporary,

$\Pi_{e 3}=-F+\pi_{e b}+\pi_{e n}$

Obviously,

$\Pi_{e 1<} \Pi_{e 3<} \Pi_{e 2}$.

Thus, extortion is likely to occur in case three, less likely to emerge in case two, and will not occur in the case one ${ }^{21}$. This example shows that it might be optimal

\footnotetext{
${ }^{21}$ Remember, we assumed that the costs of extortion are such that it would not occur if there were no barriers to entry to the private sector.
} 
for the government to announce that the barriers to entry will be removed in the near future. This way it can pre-empt the emergence of extortion.

This section showed that there exist extortion costs such that corruption occurs if the barriers to entry are imposed and remain when entry restrictions are abolished while it would not have occurred if the barriers to entry were not present in the first place. Then it was showed, that if for some reason the government would still want to impose temporary restrictions it would pay off to announce that the restrictions are temporary. The same argument can be applied to the restrictions present in the minds of the population. It would pay off to provide such an environment that the restrictions might disappear as soon as possible and their temporary nature may be understood.

The next section presents an empirical illustration of the association between entry restrictions and long-term extortion in the countries of transition.

\section{Empirical illustration}

Extortion may be exercised by government officials or private persons. In the first case extortion is a form of corruption. Unfortunately it is almost impossible to find reasonable data on extortion. However, data on corruption are readily accessible. So I use the data for corruption as the proxy for extortion.

This section provides an empirical illustration for the association between the barriers to entry present at the very beginning of transition and the level of corruption later on (in 1998). I find out that the important factor for the level of corruption in 1998 was the size of private sector in 1991, and it is not important what happened to the private sector later. This finding supports the idea that the barriers to entry, which are reflected in the size of the private sector, can substantially influence the spread of 
extortion. The analysis below is subject to some limitations, which I will discuss later, and should be understood only as illustration and in no way as a proof.

\subsection{Methodology and the data}

There are two factors that influence the spread of corruption and extortion in the countries in transition. The first one is the existence of a market niche after the break down of the communistic regime. The second is the speed with which the niche was filled by private sector enterprises. The larger the niche and the slower the private sector development, the higher the profits of the private enterprises are likely to be, and the more probable it is that corruption and extortion will develop.

Thus, it is necessary to test the dependence of extortion and corruption on the both of these factors. A good proxy for the size of market niche is the private sector as a proportion of GDP in the first years of transition. I assume that private firms, being more flexible and more profit-oriented, are, compared to state sector firms, more willing to fill in the market niche. Thus, the lower the output of private firms, the less satisfied are consumers, and the bigger is the market niche. A good proxy for the second factor-the speed of filling the niche-is the speed of private sector development. Logically, it can be measured by the change in the output of the private sector over time.

The output of the private sector as a proportion of GDP in transition countries has been estimated by EBRD, and published in their Transition Report 1999. They report their estimates from 1990 to 1998. The estimates include both the official private sector and the shadow economy, when measures of the latter were available.

Unfortunately, it is difficult to judge which year to choose so that the private sector in this year might be used as the proxy for the market niche at the beginning of 
transition, and the development of the private sector later on might be used as a proxy for private sector development. Intuitively the year might lie between 1990 and 1993 before the actual privatisation began in most countries. However, in order to make the analysis more general it seems sensible to try all the years between 1990 and 1998 as break down points.

As a proxy for corruption in this paper I use the corruption perception indices (CPI) produced by Transparency International. I use 1998 indices since this was the first year they started to report CPI for wide variety of countries in transition. For a list of the countries used and the data, see Appendix 1.

$\mathrm{CPI}$ is a continuous variable that varies from one (enormous corruption) to ten (no corruption). The private sector as a proportion of GDP at the beginning of transition and the change in the private sector during transition, are also continuous. Thus, OLS regression provides consistent and efficient estimates.

\subsection{Results}

As was discussed in the previous section a larger private sector at the beginning of transition and a higher speed of its development should lead to a lower the corruption perception index. Results are presented in Table 1. 


\section{Table 1. OLS regression results}

Dependent variable: Corruption Perception Index 1999

Independent variables: private sector as percentage of GDP in year $\mathrm{X}$, change in private sector as percentage of GDP $1998-\mathrm{X}^{22}$

\begin{tabular}{|c|c|c|c|c|}
\hline Year X & Constant & $\begin{array}{l}\text { Private sector in } \\
\text { the year } X\end{array}$ & $\begin{array}{c}\text { Change in } \\
\text { private sector } \\
\text { after the year } X \\
\text { till } 1998\end{array}$ & $\mathbf{R}^{2}$ \\
\hline 1990 & $\begin{array}{c}0.64 \\
(0.54)\end{array}$ & $\begin{array}{c}0.07^{\mathrm{c}} \\
(0.05)\end{array}$ & $\begin{array}{c}0.03^{\mathrm{c}} \\
(0.06)\end{array}$ & 0.36 \\
\hline 1991 & $\begin{array}{c}0.75 \\
(0.46) \\
\end{array}$ & $\begin{array}{c}0.06^{\mathrm{b}} \\
(0.02)\end{array}$ & $\begin{array}{r}0.03^{\mathrm{c}} \\
(0.07) \\
\end{array}$ & 0.37 \\
\hline 1992 & $\begin{array}{l}1.49 \\
(0.13) \\
\end{array}$ & $\begin{array}{l}0.07^{\mathrm{a}} \\
(0.00) \\
\end{array}$ & $\begin{array}{c}0.00 \\
(0.79) \\
\end{array}$ & 0.51 \\
\hline 1993 & $\begin{array}{l}2.24^{\mathrm{b}} \\
(0.03)\end{array}$ & $\begin{array}{c}0.05^{\mathrm{a}} \\
(0.00)\end{array}$ & $\begin{array}{l}-0.01 \\
(0.47)\end{array}$ & 0.58 \\
\hline 1994 & $\begin{array}{l}1.86^{\mathrm{c}} \\
(0.06)\end{array}$ & $\begin{array}{c}0.04^{\mathrm{a}} \\
(0.00)\end{array}$ & $\begin{array}{l}-0.01 \\
(0.54) \\
\end{array}$ & 0.56 \\
\hline 1995 & $\begin{array}{r}1.66^{\mathrm{c}} \\
(0.09) \\
\end{array}$ & $\begin{array}{c}0.04^{\mathrm{a}} \\
(0.00)\end{array}$ & $\begin{array}{c}-0.02 \\
(0.45) \\
\end{array}$ & 0.54 \\
\hline 1996 & $\begin{array}{c}1.24 \\
(0.23)\end{array}$ & $\begin{array}{l}0.04^{\mathrm{b}} \\
(0.01)\end{array}$ & $\begin{array}{l}-0.01 \\
(0.70)\end{array}$ & 0.44 \\
\hline 1997 & $\begin{array}{c}0.69 \\
(0.52)\end{array}$ & $\begin{array}{c}0.04^{\mathrm{b}} \\
(0.02)\end{array}$ & $\begin{array}{c}0.02 \\
(0.70)\end{array}$ & 0.32 \\
\hline 1998 & $\begin{array}{c}0.69 \\
(0.50)\end{array}$ & $\begin{array}{c}0.04^{\mathrm{b}} \\
(0.01)\end{array}$ & NA & 0.31 \\
\hline
\end{tabular}

P-value is in parenthesis

a - significant at $1 \%$ level

b - significant at $5 \%$ level

c- significant at $10 \%$ level

Note: the higher the Corruption Perception Index is, the less corrupt the country is likely to be.

As one can see, private sector development is an important determinant of corruption. The $\mathrm{R}^{2}$ in regressions with a break-year ranging from 1992 to 1995 are larger than 0.5 , which represents a surprisingly good fit given the quality of the data. It is very instructive, that the speed of private sector development loses its significance after 1991. Having in mind that private firms, the outputs of which are reflected in

\footnotetext{
${ }^{22}$ The results do not change if instead of change of private sector I use the normalized change, i.e. $(P S(1998)-P S(X) /(100 \%-P S(X))$.
} 
1991 private sector data, were opened long before this date, and, thus, reflect the barriers to entry present a couple of years before: possibly in 1989 or 1990.

This finding supports the idea that the private sector that existed under the communist regime or developed at the very beginning of transition is highly associated with the spread of corruption later on. In other words, the barriers to entry at the very beginning of transition, be they government imposed or inherited in the population, might bring long-term negative consequences in the spread of corruption.

\subsection{Limitations of the analysis above}

The analysis above has some limitations. Firstly, much of the data on transition economies are subject to error. It is almost impossible to estimate the GDP in many of the countries in transition, especially in the countries of the former Soviet Union. Governments of some countries tend to overestimate the numbers for political purposes, the methodology for aggregations is old, different across countries and unclear, many firms operate in the shadow economy avoiding taxes, etc. For similar reasons, it is very hard to estimate the private sector as a proportion of GDP. Thus, the data necessarily includes an error component.

Secondly, there might exist other variables, that influence the relationship. Naturally, legislation and law enforcement matters; there might be greater cultural prerequisites for corruption in some countries and corruption under the communist regime in some countries might have been higher than in others.

Thirdly, corruption in 1998 may be correlated to the private sector as a percentage of GDP in 1993 through corruption in 1991: the private sector in 1993 might have been small because of high corruption in 1991, which was than reflected in corruption in 1998. Unfortunately, corruption perception indices were not produced 
in 1991 for many countries in transition, and, thus, it is not possible to test this relationship.

Next, since the data on the private sector as a proportion of GDP include the shadow economy, part of the association between corruption perceptions and the private sector might be due to the obvious relationship between corruption and the shadow economy.

Finally, private firms, which started at advanced stages of transition are likely to be very different than those at the beginning of transition due to privatisation. A vast majority of former state owned firms were privatised after 1991. These firms may be slower in changing their orientation in order to satisfy consumers' demands, and filling in the market niche, than newly emerging private companies, and, thus, are ill suited for the argument of this paper.

Thus, the finding above should be viewed only as suggestive but in no way as proof.

\section{Conclusions and policy implications}

This paper argues that barriers to entry to the private sector at the very beginning of transition are an important determinant of the spread of corruption and extortion. If the private sector develops slowly, the first few firms are likely to have huge profits, which represent the wealth that can be easily grabbed by either bureaucrats, or racketeers, or both. The greater the barriers to entry are, the higher the profits are, and the more probable it is that extortion and corruption will spread.

Barriers to entry in this context should be understood in the most general way: both the actual barriers imposed by the state and barriers in the minds of the population, which reduce their willingness to start private businesses. Both types of 
barrier are likely to be temporary. The state imposed restrictions will most probably be abolished as transition proceeds. Meanwhile, information about the market, the lack of which would prevent the population from entering the private sector, is likely to be acquired. However, the corruption and extortion that developed due to the barriers may be permanent. The permanent nature of corruption and extortion depends on whether the population learns how the market operates from their predecessors on the market, a likely situation in the countries in transition.

If the population assesses their prospective profits from private entrepreneurship using the experience of the firms already in the market, they are likely to expect corruption and extortion if their predecessors were extorted. Thus, when the barriers to entry are removed, potential entrents will expect that they will be extorted. These expectations reduce the prospective profits from private entrepreneurship and diminish the number of people who would want to start businesses as compared to the case where no barriers to entry had been imposed. The few private firms on the market are likely to earn large pre-extortion profits, thus, reinforcing the desire of the racketeers and bureaucrats to extort. This way corruption and extortion may become permanent.

The theoretical argumentation above is supported by the empirical analysis. The development of the private sector at the very beginning of transition (before 1992) is an important determinant of corruption in 1999. The changes in the private sector that took place after this year do not significantly affect the long-term spread of corruption

From everything that was said above it seems reasonable to advise the government at the very beginning of transition to devote much effort to encourage private sector development, rather then suppressing it. Similarly, it seems very 
important to provide foreign aid at the very beginning of transition in a form that would reduce the reluctance of the citizens to start private businesses. Foreign helpers may choose to provide to the general public more information about the ways to operate private businesses, support private businesses with all types of loans, etc. It does not seem wise to give money to state officials because it increases their potential wealth-to-grab and reinforces bureaucratic extortion. 


\section{References}

De Soto, Hernando. 1989. The Other Path, New York, Harper and Row.

Diamond, Peter and Drew Fudenberg. 1987. "Rational-Expectations Business Cycles in Search Equilibrium" Journal of Political Economy, 97(3), June, p. 60619.

Frye, Timothy and Andrei Shleifer. 1997. "The Invisible Hand and the Grabbing Hand" American Economic Review, 87 (2), May, p. 354-358.

Farrell, J, and Saloner G. 1986. "Installed Base and Compatibility: Innovation, Product Preannouncements, and Predation," American Economic Review, LXXVI p. 940-955.

Goldman Marshall I. 1996. "Why Is the Mafia So Dominant in Russia?" Challenge, January-February, 39-47.

Hay, Jonathan R., Andrei Shleifer , and Robert W. Vishny. (1996) "Toward a Theory of Legal Reform,” European Economic Review, 40, p. 559-567.

Howitt, P. and R. McAfee. 1988. "Stability of Equilibria with Externalities" Quarterly Journal of Economics, CIII p. 261-278.

Johnson, Simon, Daniel Kaufmann, John McMillan and Christopher Woodruff. 1999. "Why Do Firms Hide?: Bribes and Unofficial Economy after Communism" mimeo.

Johnson, Simon, Daniel Kaufmann and Andrei Shleifer. (1997) "The Unofficial Economy in Transition" Brookings Papers on Economic Activity, 2: p. 159-239.

Krugman P. 1991. "History Versus Expectations" The Quarterly Journal of Economics, May, p. 651-667.

Matsuyama K. 1991. "Increasing Returns, Industrialisation, and Indeterminacy of Equilibrium" The Quarterly Journal of Economics, May, p. 617-650.

Roland G. and Verdier T. 1999. "Law Enforcement in Transition" mimeo ECARE and DELTA.

Roland G. 1999. "Economics of Transition" mimeo. 


\section{Appendix 1}

Private sector as percentage of GDP (PS) and corruption perception indices (CPI)

\begin{tabular}{|l|r|r|r|r|r|r|r|r|r|r|r|}
\hline & PS 1990 & PS 1991 & PS 1992 & PS 1993 & PS 1994 & PS 1995 & PS 1996 & PS 1997 & PS 1998 & CPI 1999 \\
\hline Azerbaijan & $\mathbf{1 0}$ & $\mathbf{1 0}$ & $\mathbf{1 0}$ & $\mathbf{1 0}$ & $\mathbf{2 0}$ & $\mathbf{2 5}$ & $\mathbf{2 5}$ & $\mathbf{4 0}$ & $\mathbf{5 0}$ & $\mathbf{1 . 7}$ \\
\hline Belarus & $\mathbf{5}$ & $\mathbf{5}$ & $\mathbf{1 0}$ & $\mathbf{1 0}$ & $\mathbf{1 5}$ & $\mathbf{1 5}$ & $\mathbf{1 5}$ & $\mathbf{2 0}$ & $\mathbf{2 0}$ & $\mathbf{3 . 4}$ \\
\hline Bulgaria & $\mathbf{1 0}$ & $\mathbf{1 5}$ & $\mathbf{2 5}$ & $\mathbf{3 5}$ & $\mathbf{4 0}$ & $\mathbf{4 5}$ & $\mathbf{4 5}$ & $\mathbf{5 0}$ & $\mathbf{6 5}$ & $\mathbf{3 . 3}$ \\
\hline Czech Republic & $\mathbf{1 0}$ & $\mathbf{1 5}$ & $\mathbf{3 0}$ & $\mathbf{4 5}$ & $\mathbf{6 5}$ & $\mathbf{7 0}$ & $\mathbf{7 5}$ & $\mathbf{7 5}$ & $\mathbf{7 5}$ & $\mathbf{4 . 6}$ \\
\hline Estonia & $\mathbf{1 0}$ & $\mathbf{1 0}$ & $\mathbf{2 5}$ & $\mathbf{4 0}$ & $\mathbf{5 5}$ & $\mathbf{6 5}$ & $\mathbf{7 0}$ & $\mathbf{7 0}$ & $\mathbf{7 0}$ & $\mathbf{5 . 7}$ \\
\hline Georgia & $\mathbf{1 5}$ & $\mathbf{1 5}$ & $\mathbf{1 5}$ & $\mathbf{2 0}$ & $\mathbf{2 0}$ & $\mathbf{3 0}$ & $\mathbf{5 0}$ & $\mathbf{5 5}$ & $\mathbf{5 5}$ & $\mathbf{2 . 3}$ \\
\hline Hungary & $\mathbf{2 5}$ & $\mathbf{3 0}$ & $\mathbf{4 0}$ & $\mathbf{5 0}$ & $\mathbf{5 5}$ & $\mathbf{6 0}$ & $\mathbf{7 0}$ & $\mathbf{7 5}$ & $\mathbf{8 5}$ & $\mathbf{5 . 2}$ \\
\hline Kazakhstan & $\mathbf{5}$ & $\mathbf{5}$ & $\mathbf{1 0}$ & $\mathbf{1 0}$ & $\mathbf{2 0}$ & $\mathbf{2 5}$ & $\mathbf{4 0}$ & $\mathbf{5 5}$ & $\mathbf{5 5}$ & $\mathbf{2 . 3}$ \\
\hline Latvia & $\mathbf{1 0}$ & $\mathbf{1 0}$ & $\mathbf{2 5}$ & $\mathbf{3 0}$ & $\mathbf{4 0}$ & $\mathbf{5 5}$ & $\mathbf{6 0}$ & $\mathbf{6 0}$ & $\mathbf{6 5}$ & $\mathbf{3 . 4}$ \\
\hline Lithuania & $\mathbf{1 0}$ & $\mathbf{1 0}$ & $\mathbf{2 0}$ & $\mathbf{3 5}$ & $\mathbf{6 0}$ & $\mathbf{6 5}$ & $\mathbf{7 0}$ & $\mathbf{7 0}$ & $\mathbf{7 0}$ & $\mathbf{3 . 8}$ \\
\hline Moldova & $\mathbf{1 0}$ & $\mathbf{1 0}$ & $\mathbf{1 0}$ & $\mathbf{1 5}$ & $\mathbf{2 0}$ & $\mathbf{3 0}$ & $\mathbf{4 0}$ & $\mathbf{4 5}$ & $\mathbf{5 0}$ & $\mathbf{2 . 6}$ \\
\hline Poland & $\mathbf{3 0}$ & $\mathbf{4 0}$ & $\mathbf{4 5}$ & $\mathbf{5 0}$ & $\mathbf{5 5}$ & $\mathbf{6 0}$ & $\mathbf{6 0}$ & $\mathbf{6 5}$ & $\mathbf{6 5}$ & $\mathbf{4 . 2}$ \\
\hline Romania & $\mathbf{1 5}$ & $\mathbf{2 5}$ & $\mathbf{2 5}$ & $\mathbf{3 0}$ & $\mathbf{3 5}$ & $\mathbf{4 0}$ & $\mathbf{6 0}$ & $\mathbf{6 0}$ & $\mathbf{6 0}$ & $\mathbf{3 . 3}$ \\
\hline Russia & $\mathbf{5}$ & $\mathbf{5}$ & $\mathbf{2 5}$ & $\mathbf{4 0}$ & $\mathbf{5 0}$ & $\mathbf{5 5}$ & $\mathbf{6 0}$ & $\mathbf{7 0}$ & $\mathbf{7 0}$ & $\mathbf{2 . 4}$ \\
\hline Slovak Republic & $\mathbf{1 0}$ & $\mathbf{1 5}$ & $\mathbf{3 0}$ & $\mathbf{4 5}$ & $\mathbf{5 5}$ & $\mathbf{6 0}$ & $\mathbf{7 0}$ & $\mathbf{7 5}$ & $\mathbf{7 5}$ & $\mathbf{3 . 7}$ \\
\hline Ukraine & $\mathbf{1 0}$ & $\mathbf{1 0}$ & $\mathbf{1 0}$ & $\mathbf{1 5}$ & $\mathbf{4 0}$ & $\mathbf{4 5}$ & $\mathbf{5 0}$ & $\mathbf{5 5}$ & $\mathbf{5 5}$ & $\mathbf{2 . 6}$ \\
\hline Uzbekistan & $\mathbf{1 0}$ & $\mathbf{1 0}$ & $\mathbf{1 0}$ & $\mathbf{1 5}$ & $\mathbf{2 0}$ & $\mathbf{3 0}$ & $\mathbf{4 0}$ & $\mathbf{4 5}$ & $\mathbf{4 5}$ & $\mathbf{1 . 8}$ \\
\hline
\end{tabular}

Sources:

Private sector as a percentage of GDP - EBRD estimates, Transition report 1999.

Corruption perception indices - estimates of Transparency International 